\title{
Programmed Death Ligand 1 (PD-L1) Expression in Lung Adenocarcinoma Patients
}

\section{Rahmat Hidayat ${ }^{1}$, Noni Novisari Soeroso ${ }^{2}$, Elisna Syahruddin ${ }^{3}$, Evlin Suzanna ${ }^{4}$, Dian Cahyadi ${ }^{5}$, Setiaputra ${ }^{6}$}

1,2,6Department of Pulmonology and Respiratory Medicine, Faculty of Medicine, Universitas Sumatera Utara, Medan

${ }^{3}$ Department of Pulmonology and Respiratory Medicine, Faculty of Medicine, Universitas Indonesia, Jakarta

${ }^{4,5}$ Department of Anatomical Pathology, Faculty of Medicine, Universitas Indonesia - Dharmais Hospital, Jakarta

\section{Corresponding Author:}

Rahmad Hidayat | Department of Pulmonology and Respiratory Medicine, Faculty of Medicine, Universitas Sumatera Utara, Medan | drrahmat3@gmail.com

Submitted: February $19^{\text {th }}, 2021$

Accepted: March $1^{\text {st }}, 2021$

Published: June $23^{\text {th }}, 2021$

Respir Sci. 2021; 1(3): 162-165

https://doi.org/10.36497/respirsci.v1i3.16

\section{Abstract}

Background: Programmed Death Ligand 1 (PD-L1) is a protein found in tumor cells that could inactivate T-cells. This research was done to identify the characteristics of lung adenocarcinoma patients to PD-L1 expression in Medan.

Method: Descriptive research with a cross-sectional design was used and the study was done for 12 months (January - December 2018). Sample's collection was done at RSUP (Central Public Hospital) H. Adam Malik and the samples diagnosed with lung adenocarcinoma based on histopathological subtyping were sent to the laboratory of Dharmais Jakarta Hospital where the Ventana 22C3 Immunohistochemistry Staining was done.

Results: Staining was done in 52 samples at Dharmais Jakarta Hospital and only 35 samples were deemed acceptable. In this study, participants' ages ranged from 40 to 60 years, where the majority were male patients, $31(88.6 \%)$ and 33 patients $(82.5 \%)$ were at an advanced stage (III and IV).

Conclusion: The study found that the PD-L1 expression was mostly observed in male at the age range of $40-60$ years and stage IV lung adenocarcinoma patients with Tumour Proportion Score (TPS) of $1-49 \%$.

Keywords: Programmed Death Ligand 1 (PD-L1), lung adenocarcinoma, Tumour Proportion Score (TPS), Immunohistochemistry

\section{INTRODUCTION}

Lung cancer is considered the leading cause of death worldwide, and the Global Cancer Observatory (Globocan) predicted there were approximately 234,555 deaths in Indonesia due to this disease. ${ }^{1}$ Lung adenocarcinoma is one of the more commonly found type of lung cancer. ${ }^{2}$ According to Melindawati (2008), lung cancer patients in $\mathrm{H}$. Adam Malik Central Public Hospital have increased by 378 within 2004-2008. Based on the cell types, non-small cell lung cancer (NSCLC) is the most common type (99\%), which is further 
classified into adenocarcinoma (56.3\%), squamous-cell carcinoma (40.7\%), and large-cell carcinoma (2\%), whereas the remaining $1 \%$ is identified as small cell lung cancer (SCLC). ${ }^{3}$

The growth of this disease has led to the breakthrough in immunology research to increase the life expectancy in lung cancer patients with lung adenocarcinoma type. The interaction between the immune system and tumor cells during disease progression could induce metastasis., ${ }^{4,5}$

A study by Igarashi (2018) showed that the alveolar macrophages in the tissue specimens from tumor cells were stained with Programmed Death Ligand 1 (PD-L1) and administration of inhibitor in PD-L1 and PD-1 was suggested to increase the life expectancy in advanced stage lung cancer patients. PD-L1 expression is used as a biomarker to predict the patients' positive response to immunotherapy. The understanding of PD-L1 as a biomarker can be reviewed by using different protein with different PD-L1 antibody, a scoring system known as Tumour Proportion Score (TPS), which calculate the percentage of viable tumor cells showing partial or complete membrane staining $(>1+)$ relative to the available tumor cells within the sample (positive and negative), and the interaction between Programmed Cell Death Protein 1 (PD-1) and PD-L1 therapy with immunotherapy clinical trial. ${ }^{6}$

\section{METHOD}

A cross-sectional design was used in this study with sample characteristics of patients that have been diagnosed with lung adenocarcinoma based on histopathological subtyping at $\mathrm{H}$. Adam Malik Central Public Hospital within January-December 2018. The collected specimens that have met the inclusion criteria, such as lung adenocarcinoma diagnosis based on histopathological subtyping, were sent to the Laboratory of Anatomical Pathology at Dharmais Jakarta Hospital and rechecked by the assigned pathologists. Immunohistochemistry staining was done afterward, and the specimens were classified into four different types based on the TPS score, which were $>50 \%$ (strong positive expression), $1-49 \%,<1 \%$ and $0 \%$. This study has been approved by the Ethical Research Committee of the Faculty of Medicine, Universitas Sumatera Utara.

\section{RESULT}

Based on inclusion criteria, only 35 out of the 52 samples were accepted and studied further, 17 samples could not be identified due to insufficient tumor cells. The data showed that the subject characteristics were in the age range of 4060 years, the majority being male, 31 patients (88.6\%). Sixteen patients (45.7\%) were identified as light smokers based on the low Brinkman Index (BI) and 33 patients $(82.5 \%)$ were in an advanced clinical stage (III and IV). The details could be seen in Table 1.

It can be seen from table 2 that more than half of the patients $(51.4 \%)$ obtained a TPS of $1-49 \%$, followed by TPS of $>50 \%$ 
in 8 patients (22.9\%), $0 \%$ in 6 patients $(17.1 \%)$ and $<1 \%$ in 3 patients (8.6\%).

Table 1. Characteristics distribution based on gender, age, smoking status, and clinical cancer stage.

\begin{tabular}{|c|c|c|}
\hline Characteristics & $\begin{array}{c}\text { Frequency } \\
n=35\end{array}$ & $\begin{array}{c}\text { Percentage } \\
(\%)\end{array}$ \\
\hline \multicolumn{3}{|l|}{ Gender } \\
\hline Male & 31 & 88.6 \\
\hline Female & 4 & 11.4 \\
\hline \multicolumn{3}{|l|}{ Age } \\
\hline $40-60$ & 20 & 57.1 \\
\hline 60 & 15 & 42.9 \\
\hline \multicolumn{3}{|l|}{ Clinical Stage } \\
\hline IIIA & 2 & 5.7 \\
\hline IIIB & 5 & 14.3 \\
\hline IIIC & 2 & 5.7 \\
\hline IVA & 24 & 68.6 \\
\hline IVB & 2 & 5.7 \\
\hline
\end{tabular}

Table 2. TPS Distribution of PD-L1

\begin{tabular}{ccc}
\hline TPS & $\begin{array}{c}\text { Frequency } \\
\mathrm{n}=35\end{array}$ & $\begin{array}{c}\text { Percentage } \\
(\%)\end{array}$ \\
\hline $0 \%$ & 6 & 17.1 \\
$<1 \%$ & 3 & 8.6 \\
$1-49 \%$ & 18 & 51.4 \\
$\geq 50 \%$ & 8 & 22.9 \\
\hline
\end{tabular}

\section{DISCUSSION}

The results showed the majority of lung adenocarcinoma patients in this study were male, $31(88.6 \%)$ and only 4 patients were female (11.4\%). A similar trend was seen in the study by Azuma et al. which reported 91 out of the 164 participants were male (55\%). Lung cancer was the second most malignant type of cancer observed in men (13.4\%) after nasopharyngeal cancer (13.63\%) and was the main leading cause of death in men (28.94\%). Research by Janzic et al. showed that more than half $(63 \%)$ of the patients, which was 34 , were male and only 20 patients (37\%) were female. ${ }^{4,5}$
The age distribution of the participants was mostly within $40-60$ years. A study suggested that the incidence of lung cancer remained low at the age $<40$ years although it would increase with age up until 70 years. $^{7}$ Median age of the patients in research by Azuma et al. was 66 years (39-82 years) ${ }^{5}$ whereas Lin et al. reported a median of 56 years (34-78 years) at the time of diagnosis. ${ }^{7}$

The numbers of patients with clinical stage of IIIA, IIIB, IIIC, IVA, and IVB were reported to be $2(5.7 \%), 5(14.3 \%), 2$ $(5.7 \%)$, and $24(68.6 \%)$, and $2(5.7 \%)$, respectively. Sixty-seven patients $(40.8 \%)$, $46(28 \%)$, and $51(31 \%)$ were at stage I, II, and III, respectively in a study by Azuma et al. ${ }^{5}$ Lin et al. reported the patients at stage I, II and III were 50 patients $(29.4 \%), 43(25.3 \%)$, and 77 patients (45.3\%), respectively. The study suggested that higher tumor stage showed a higher significance in PD-L1 expression and it was confirmed to be an independent factor on the higher incidence of the expression significantly. Furthermore, Lin et al. reported that the highest PD-L1 expression was observed in patients at the advanced stage (III and IV), which were 21 subjects $(63.4 \%){ }^{7}$

The TPS score on PD-L1 expression showed that most patients, 18 (51.4\%), obtained a score of $1-49 \%$. A study by Zhang et al. suggested that higher incidence of PD-L1 expression were observed in male, smokers, and advancedstage lung cancer patients. ${ }^{8}$

There are several limitations to our study, data were collected based on 
observational and retrospective, lack information about the previous treatment to patients, the most of the samples were found minimally or insufficient to be stained.

We would like to thank IASTO and the Laboratory of Anatomical Pathology of Dharmais Hospital for their help and support in this research.

\section{CONCLUSION}

The study has reported that the age range of the lung adenocarcinoma patients was 40-60 years, with the majority being male, 31 patients (88.6\%). Furthermore, 16 patients were identified as light smokers based on the low BI (45.7\%) and 33 participants were in an advanced clinical stage (III and IV) (82.5\%).

\section{REFERENCES}

1. Globocan-IARC. Estimated cancer incidence, mortality and prevalence worldwide in 2012. International Agency for Research on Cancer, World Health Organization. http://globocan.iarc.fr/Pages/fact_sh eets_cancer.aspx. Published 2020. Accessed January 12, 2021.

2. American Cancer Society. Cancer Facts \& Figures. Atlanta: American Cancer Society; 2017.

3. Saragih HM. Profil Penderita Kanker Paru Yang Dirawat di Rindu A3 RA3) RSUP. H. Adam Malik Medan Tahun 2007-2010. 2012:28-30.

4. Azuma K, Ota K, Kawahara A, et al. Association of PD-L1 overexpression with activating EGFR mutations in surgically resected nonsmall-cell lung cancer. Ann

Oncol. 2014;25(10):1935-1940.

5. Janzic U, Kern I, Janzic A, Cavka L, Cufer T. PD-L1 expression in squamous-cell carcinoma and adenocarcinoma of the lung. Radiol Oncol. 2017;51(3):357-362.

6. Igarashi $T$, Teramoto $K$, Ishida $M$, Hanaoka J, Daigo Y. Scoring of PD-L1 expression intensity on pulmonary adenocarcinomas and the correlations with clinicopathological factors. ESMO Open. 2016;1(4):e000083.

7. Lin G, Fan X, Zhu W, et al. Prognostic significance of PD-L1 expression and tumor infiltrating lymphocyte in surgically resectable non-small cell lung cancer. Oncotarget. 2017;8(48):83986-83994.

8. Zhang $M$, Feng $D$, Jing $J$, Liu $H$, Zhao S, Zhang Q. PD-L1 protein expression in non-small cell lung cancer based on different immunohistochemical antibodies. J Thorac Dis. 2017;9(5):E470-E473. 